\title{
Predestinasi
}

Volume 13, No. 2, Desember 2020, Hal. 93- 106

ISSN (Print): 1978-9351

\section{Strategic Interest and Media: A Global Perspective}

\author{
Davina Nyiam \\ Department of Mass Communication, \\ Cross River University of Technology (CRUTECH) \\ Munene, Calabar South 540252, Calabar, Nigeria \\ *e-mail: davinadavid4real@yahoo.com
}

\begin{abstract}
Media has also been used as psychological warfare and a propaganda tool, particularly during times of wars and acts of insurgency. It has been used as a tool while fighting the wars and boosting the morale of the security forces across the nations. Propaganda, although it has existed almost indefinitely, has grown immensely during the past few centuries as a most strategic tool to guard the strategic interests of the nations. The propaganda was bolstered by the invention of the radio. The ability to communicate orally with a large number of people in a very small amount of time also helped the development of propaganda. This form of mass media has been used as the most effective tool with the government agencies to put forth their news and views. Radio has strategically suited governments across the globe to fight psychological wars by airing propaganda into the territories of the neighbouring countries. Since Radio is affordable and speaks in a local language and customs to a very common man, it has definitely an edge over other formats of communication when it comes to the question of guarding the strategic interests of a nation. This research discusses and deals with the strategic interests and the media and how radio has especially been used worldwide as a tool by a number of countries to safeguard their national interests. This chapter touches upon some theories and elements of propaganda, the use of radio during world wars and how countries guarded their strategic interests in the Cold War and PostCold War era.
\end{abstract}

Keywords: Media; Strategic Interests; Cold War; Post-Cold War era.

\section{INTRODUCTION}

Nations across the world, believing in any system or form of government, have been using media under their control as a tool to defend and safeguard their strategic interests. While the sovereign and democratic countries have been/are using media in propagating the essence of democracy within the State and in their neighborhood, countries ruled by kings, monarchs or military generals, had equally used media in disseminating whatever suited their individual and collective strategic interests. The Capitalist and the Communist nations have also not lagged behind in using media under their control against each other for lobbying, thrusting, generating and containing opinions besides projecting their exclusive viewpoints and ideologies. However, irrespective of the fact whether nations believing in democracy, monarchism, dictatorship or driven by religious extremism, the governments over the years have overtly and covertly used 


\author{
94 Predestinasi \\ Volume 14, No. 1, Juni 2020 Hal. 93- 106
}

media under their control as a vital tool to promote their national policies and to defend their strategic interests during the times of both peace and conflicts (Edet 2005; Edet 2019).

There is no greater power in the world today than that wielded by the manipulators of public opinion. It is the power of media that virtually shapes and moulds the mind of every citizen; young or old, rich or poor, simple or sophisticated. The mass media forms an image of the world for every citizen and tells what to think about that image. Essentially, everything we know or think we know comes to us via our daily newspapers, radio, or television. The way in which the news is covered; which items are emphasized and which are played down, the reporter's choice of words, tone of voice, music and facial expressions; the wording of headlines; the choice of illustrations -- all of these things subliminally and yet profoundly affect the way in which we interpret what we see or hear. Since mass media does not only circulate news but also provides information on vital and different aspects of life and its problems and also helps in promoting sale; it has thus been used as a strong tool to disseminate views, thoughts, policies facts and guided the governments in approaching the people in times of crisis and strains. In democratic regimes like the United States of America and Nigeria, media is considered as a mirror that reflects the general orientation of political life and the microscope allowing citizens to pay attention to different national activities and by expressing their opinion. It contributes to the progress of the nation. A modern democratic state, therefore, cannot ensure its durability except by permanent communication between its citizens and the different wheels of power (Iosifidis \& Wheeler 2019). Nowadays, no one denies the role of media in consolidating social cohesion and development action. The freedom of speech and passage of information is, therefore, legitimate in a developed and developing society where fundamental rights are guaranteed under the Constitution. But then individual freedoms have restrictions, more so when the national security and its strategic interests are involved. Despite the fact that the right to information is the fundamental right in any democratic set-up where media is considered the fourth pillar of democracy, yet security and strategic interests are of paramount importance for any country facing a hostile environment, conditions or internal and external pulls and pressures.

As a strategic tool, the nations, since their creations, have as such often used media as a promoter of national interests. They have equally used media as a strong psychological warfare or propaganda machinery in times of crisis. While aggressors have used media under their control as a tool to fight wars, history is witness to the fact that those nations upon whom wars were thrust upon, had to use their media in counter-propaganda operations and to boost the morale of their security forces; a mention of which has also been made in a famous reference book 'Propaganda Techniques in the World War' (Lasswell, 1927). This book has an all-time relevance, since propaganda and counter-propaganda have remained a vital strategic segment in almost all full-fledged, cold and proxy wars fought across the globe during the past nine decades. A review of the book, asks the politicians, strategists, generals, admirals and journalists to learn the art of lying for the advantage of their respective countries. It says "without lying, no presentday war can successfully be waged. The airplanes in the wars will be hideous instruments of death to whole cities together, but the lie, used as a propaganda and strategic tool, also flies by air and is more powerful even than the fighter planes" (Lasswell,1927, p. 45). The book suggests that side by side with strategy, the tactics and armament of lying should also be studied in all military and naval schools; and especially in media offices, where the knowledge is more easily obtainable (Lasswell, 1927).

However, this theory is differed by some media experts, who opine that while liberty can be taken in the manner of presentation of truth or to the extent to which it is to be given during war, news or a false story, should never be put out. Even in psychological propaganda directed to the enemy during the times of war, a propagandist cannot afford to tell a lie while presenting news, as his first task is to ensure credibility with the people in the enemy country. His 
skill lies in selecting the particular news he wishes to put out, mix it with at least some truths of the kind that the enemy wants to hear and present it in a manner that will create an impact and will not be suspected as propaganda, even if it is. For this purpose, the propagandist should be a part of the war machinery so that he can plan his broadcast material as part of military strategy (Chatterjee 1973).

Whatever be the situation, the fact is that the media has not been used as a strategic tool during times of war only. Its relevance has been found more during times of peace when used to propagate the government's viewpoint, messages, opinions, plans and policies, besides fostering the spirit of nationhood. It has also been used as a tool to check internal conflicts, a spate of communal violence and has acted as the most reliable medium in dealing with law and order situations. Apart from its use to entertain, educate and inform the public, the media is also being used worldwide during times of crimes when nations are plunged into natural disasters and calamities.

\section{PROPAGANDA AND ITS THEORIES}

Although media propaganda has existed almost indefinitely, it has, however, grown immensely during the past nine decades as a most vital psychological weapon to suit the strategic interests of the nations both in times of peace and war. Be that American, European or Asian countries, the propaganda finds a mention everywhere and powerful and mass-based media has always been used to accomplish such types of strategic tasks. There are a number of definitions to define propaganda for different pro-government and anti-government agencies. If a particular idea suits a nation, it is termed as a policy message while as for the other nation, the same message has a negative connotation and is viewed as counter-productive. It is then termed as propaganda with dangerous ramifications and needs to be countered through mass media. However, in both situations, it is an exercise aimed at manipulating public opinion and is carried out by governments, enemy agents or even by terrorists and intelligence agencies capable of reaching a large number of people and effectively persuading them for or against a cause. Some argue that any persuasive communication is propaganda, while others hold that propaganda specifically alters political opinions and in war, truth is the first casualty (Edgley, 2002). Propaganda at the same time is material that is meant to persuade or change public opinion, and though it often varies in form and technique, it always serves the same purpose: A communication for persuasion and does not mean always something undesirable or sinister. It, however, means the scientific application, of mass communication to spread a particular point of view, an ideology or an objective, or a programme among the people with a view to inform or educate them or changing their approach or outlook. However, for some countries, it can no doubt be used to serve nefarious ends (Chatterjee 1973).

The evidence of intentional propaganda can be traced back as far as ancient Greece. However, the advent of communication media on a larger scale has exponentially increased its usage. After the invention of the printing press, it became possible to quickly and easily produce posters and books. Prior to this development, however, the majority of propaganda was spread by word of mouth. The printing press enabled the propagandists to quickly produce large amount of posters with one intended effect, a form of propaganda much less risky and difficult than oral communication. The first decade of the twentieth century had barely passed before Europe and later the United States were plunged into the war. The very division of labour and the resulting heterogeneity and individuality that had made the new industrial societies possible now became a problem. World War-I was really the first of the global struggles in which entire populations played active and coordinated roles in the effort against their enemies. As each country became 
politically committed to the war, there arose a most critical and urgent need to forge stronger links between the individual and society. It had become essential to mobilise sentiments and loyalties, to instill in citizens a hatred and fear of the enemy, to maintain their morale in the face of privation and to capture their energies into an effective contribution to their nation (DeFleur \& BallRokeach 1988).

The means for achieving these goals was propaganda. Carefully designed propaganda messages engulfed the nation in news stories, pictures, films, phonograph records, speeches, books, sermons, posters, wireless signals, rumours, billboard advertisements and handbills. Top-level policymakers decided the stakes were so high and the ends so important that they justified almost any means (DeFleur \& Ball-Rokeach 1988). Citizens had to hate the enemy, love their country and maximise commitment to the war effort. The mass media of communication available at the time became the principal tools of persuading them to do so. While different formats of communications have been used to achieve the strategic interest, the propaganda was, however, bolstered by the invention of the radio. The ability to communicate orally with large amount of people in a very small amount of time also helped the development of propaganda. During the Cold War, the rival superpowers and their respective blocks used the mass media, particularly radio, to conduct worldwide public diplomacy campaigns. The airwave battles were designed to win the minds and hearts of people around the world. To a much lesser extent, leaders and groups also used media to promote diplomacy and better understanding among rival nations (Oetzel \& Ting-Toomey 2006). In an age where we are increasingly bombarded by propaganda from a variety of media channels, it is increasingly important to recognise and understand propaganda and its effects on a society that faces both internal and external threats. Although the word "propaganda" has a negative connotation, propaganda itself is not necessarily bad, as it is an attempt to change opinions by persuasively presenting new ones. The propagandists' attempts to alter the opinions of his subjects or viewers by convincing them of the validity of their own. The purpose of propaganda is to change opinions, but more importantly to influence the decisions. By understanding the purpose of the propaganda and the method being used, one can go a long way towards making effective independent decisions (Lee \& Lee 2001). The media propaganda, based upon "Psychological Operations Field Manual No.33-1" published in August 1979 by Department of the Army Headquarters in Washington DC and "Psychological Operations (PSYOP) Media Subcourse PO-0816" by the Army Institute for Professional Development, published in 1983, are categorised as follows (http://www.psywarrior.com/links.html):

- Face to face (interpersonal communication): This is the most effective means of transmitting a persuasive message. It is employed in rallies, rumour campaigns, group discussions, lectures, show-and-tell demonstrations, social organisations, social activities, entertainment, and individual person-to-person contacts, all providing a participating experience for the individual or group to recall later.

- Audio and visual media: Radio, television, electronic tape recordings, loudspeakers and sound motion pictures are the second most effective means of communication available to the psychological operator. Effectiveness is based on seeing and hearing persuasive messages. These media formats are an excellent means of transmitting persuasive messages and eliciting a high degree of recall. They lend themselves to the transmission of brief, simple messages and to personalisation by use of the human voice. They require little or no effort by the audience and generally they have more appeal than visual media. Also, the barrier of illiteracy may be more easily overcome with audio media than with visual media (printed material).

- Themes: They are reinforced and the target audience given broad coverage by using several media to deliver the same basic message. For example, radio and television can augment leaflets; face-to-face communication can support newspaper circulation. 
However, while selecting the media to propagate the message, certain media theories and steps are required to be taken into consideration before launching the campaign for meeting the strategic interests. It is argued that the influence of various types of media varies. The newspaper is undoubtedly powerful but it is less direct than the broadcast media and certainly less intimate. The emotional response created by Winston Churchill's broadcast to the nation during the dark days of London bombing did more to build up public morale and to steel the people against reverses and vicissitudes than any mass media approach. The great Kennedy-Nixon debate in 1960 on the Presidential election emphasized the importance of the personal approach along with underlining the utility of television as a mass media (Snowden \& Green 2007). It is in this context that the general criterion for the selection of media for the government and other agencies concerned is:

- Acceptability and credibility. A complete target analysis will indicate how acceptable and credible a particular medium is to the target audience.

- Availability. The availability of media, the mechanical capability of message production, and the capability to deliver the message, as well as the ability of the audience to receive and understand it are important.

- Timeliness: Production and dissemination lag for each medium must be considered. For example, a medium requiring a long production or dissemination time would not be suitable for a message exploiting a target of opportunity.

- Quantity: The media selected should be mixed, one medium reinforcing the other, and delivered in sufficient volume to insure that the entire target is exposed to the message. Care, however, is required to prevent counterproductive over saturation of the target audience. This requires analysis of intensity and timing of propaganda dissemination.

- Themes: The theme to be conveyed will have a bearing on the selection of the best media to transmit the message.

- Suitability: The media selected must be suitable for the target audience. The selection of language, vocabulary and level of audience are also important factors. For example, it would not be appropriate to use newspapers or other printed text to deliver a message to an illiterate and that section of audience which lives in far flung areas where newspapers do not serve any purpose.

As explained earlier, the use of propaganda machinery is not confined to only during the times of war. There are evidences that the totalitarian countries undertake such kind of propaganda even in peace time on the home front and also direct it to the potential enemy countries or such other countries which are their targets of subversion. The approach of democracy, on the other hand, is quite different. History shows that in most cases, aggressive postures leading to wars come from totalitarian countries. In a democracy, the initial effort is to avoid a war, if possible. If, however, war is thrust upon a country, then the aim is to win it and use the media as a psychological tool for meeting the vital strategic interests (Chatterjee 1973).

It is important to compare here how radio sets were dealt with America versus Germany. In Nazi Germany, the production of radios, also a somewhat new development was very restrictive. Any radio that received signals of radio stations other than those put out by the German government were by all means prohibited. A radio that did not meet the requirements of the state was forbidden. The government was very strict in what radio sets were allowed in the home. Adolf Hitler, the leading force of this movement, wanted to ensure that citizens of Germany should not listen to British or French media. Unfortunately, his goal was undeniably a success. People of Germany hold learned about what the government wanted them to be aware of. For instance, some townspeople who entered concentration camps and were told to bury dead townspeople acted confused, honestly saying that they were not aware of what was going on. This was in most cases true, due to the ultimate control Nazis held over Germany. It is unbelievable how clueless many 
Germans were about the realities of what was occurring in Germany. In fact, many Germans thought they were still winning the war when Allied troops entered Germany, and most critically believed that there was no holocaust. This deception could take place as there was a complete control of Nazis over communication media. With radio, several frequencies were isolated and "Volksradios" could not tune into anything but Nazi stations. Listening to anything else meant the radio was likely modified. This was an act punishable as treason.

\section{ADVANTAGES OF RADIO AS A STRATEGIC TOOL}

The strategists and media experts propagating a particular ideology or thought process, mostly prepare catalogs of media material which applies to recurring themes and general audiences. These catalogs include printed material, loudspeaker and videotapes, motion picture films, and online items meant for psychological operations. However, since this research is mostly based on using radio as a strategic tool, here are some of the major benefits of this medium of sound: The major advantages of the Radio broadcasts are that they can be transmitted to local audiences in their own languages and dialects across the national boundaries and behind enemy lines without the support of dish antennas, visual screens or print material. Such an advantage and reach at one go is not possible for other forms of media. Political boundaries or tactical situations may hinder radio broadcasts, but they are not complete barriers. Since radio can reach mass target audiences quickly and that too in their language stuffed with emotive music, it is as such useful for all types of psychological operations. Where radio stations are not common and receivers rare or nonexistent, receivers could be airdropped or otherwise distributed to key communicators, public installations, and selected individuals. Public listener systems may also be set up and can be quickly prepared for broadcast. This is important when attempting to capitalise on targets of opportunity. The radio further has a wide coverage and can reach members of large and varied audiences simultaneously. It requires little or no effort to visualise the radio message. Illiteracy does not prevent the listener from forming his or her individual image while listening to Radio. Further, Radio is easily adaptable to drama, music, news, and other types of programmes. Also, a skilled radio announcer, who remains unidentified, can exert tremendous influence on a listener simply with pitch, resonance, mimicry, dialogue delivery, inflection or timing.

Radio programming consists of planning the schedule, content, and production of programmes during a stated period. Words, music, and sound effects and bytes are put together in various ways to produce different kinds of programmes. Some of the major types of radio programmes are straight news reports (without commentary) translated in any or most of the languages, musical (popular, folk, classical) drama, speeches, talks, discussions sports, interviews, special events; i.e., on-the-spot coverage of an election or the arrival of an important visitor, etc, religious, besides a combination of music, skits, comedy, vaudeville, etc. The frequent announcements and highly religious sermons and discourses play a major role in meeting the strategic interests of the nations of different faiths and beliefs, as the emotional tone conveyed by the voice may influence the listener more than the logic of arguments. Announcers whose accents are similar to those of targeted groups are frequently used to convince the audience. There are instances that the female voices have frequently been used in propaganda and counterpropaganda programmes to exploit nostalgia, sex frustration, or to attract female audiences (Paletz \& Schmid 1992).

The radio propaganda broadcast, like other channels of mass media, however, has its own limitations; the one amongst the list is that some countries have only single channel radios with the frequency set to the government-owned station. In some areas central receivers are connected to household receivers to control listening. The jamming may further prevent the target group from receiving radio broadcasts as the signals could be made inaudible or distorted by fading or 
static due to unfavorable atmospheric conditions. Also, oral media has no permanency like that of written media and messages may be quickly forgotten or distorted (Essien 2005; Essien 2017; Essien 2020). But then since sending of print material at a mass level across the border into enemy countries is extremely difficult, the radio here plays a major role in meeting the strategic requirements. The radio waves are easily bombarded with propaganda and counter-propaganda programmes. The internet propaganda also enjoys such kind of advantage but to propagate the message, one requires to be a technology savvy which is not required when it comes to the question of using Radio as a strategic tool. It could be because of these advantageous reasons that, while resorting to propaganda, the Governments have every time used radio as an effective medium for strategic communication (Essien 2003). Since radio has an advantage, particularly during the times of war, the medium of sound has been used by every government to put forth the news and views to politically suit them and also to fight psychological wars by airing propaganda into the territories of the neighbouring countries (Pavarala \& Malik 2017).

Even though some countries like America as democratic nations and people there are used to freedom of expression, however, during the war they too had to adjust to temporary limits on this freedom. In the interest of the nation, the Office of Censorship was the group responsible for these limitations on letters from overseas, in which they might delete some words, then, reseal and send the letter to the intended location. However, they were most responsible for the censoring of radio broadcasts. Battle casualties and news of ship and troop movements were strictly confidential and not meant to be publicised. The Office of War Information was then developed in 1942 to further the protection of American citizens. The organisation worked to defend and explain the actions of the government as well as to keep some information confidential. This group determined what government programmes were broadcast and radio stations were given facts to incorporate in their broadcasts to show they supported the government. Each week radio stations had to promise to dedicate a certain amount of time to war related programmes. War related issues were also to be worked into other specials that were not directly concerned with war, such as children's specials and dramas. Security on radio stations had also became very strict. Song requests were often denied with the possibility of an individual trying to use a song title to relay a message to another individual. Weather reports were temporary suspended with the fear that bomber pilots would over hear. Spontaneous interviews on the streets were also temporarily discontinued because of the same fear of "coded messages".

\section{ROLE OF RADIO DURING WORLD WARS}

During the decade of 1930 to 1940, it is widely believed that Radio flowered in America. It was after trying years for the American society as the Great Depression and World War-II affected the destinies of every citizen, but they had little inhabiting effect on radio which fitted the needs of millions of hard-pressed people during those hard times. It had music to restore their sagging spirit, funny people to cheer them up and dramatic news to divert their attention from their personal problems (Hilmes 1997). By the time the depression eased and World War Second was about to begin, Radio was reaching every ear. In mid-1940, there were one and a half sets per household in the United States. However, the highest importance of Radio as a national medium for every country was reinforced during World War II. Edward R. Murrow became a national figure when he broadcast from London during the early years of the war. Since there was no other mass medium of communication except Radio waves, it was this very institution used as a tool to have liaison with the armed forces and public and at the same time used it as the most strategic and effective weapon to fight wars. Following the United States' entry into the war in December 1941, millions of Americans turned to the Radio every day to hear the latest war news. The Radio industry also made its resources available to the federal government. War information 
messages, domestic propaganda, the selling of war bonds, campaigns to reduce the civilian usage of important materials and many other vital services were performed. It was also during World War II that Germany enlisted radio services of Mildred Gillars, a woman who came to be known as "Axis Sally". Gillars, a native of Portland, Maine, was a music student at Hunter College in Germany during the 1930s. She subsequently fell in love with a professor and later, during the war, he convinced her to become involved in propaganda broadcasts on behalf of Germany (Hilmes 1997). It has rightly been said the word is deadlier than the sword. One thing is for sure: when it comes to manipulating armed forces, it has often been one of the most sinister weapons ever to be employed against lonely, homesick or tired soldiers. And "Axix Sally" showed that she was competent enough to strike the psychological chord through her radio broadcasts.

In January 1942, Japan also showed its strategic interest in Radio. The land of the Rising Sun used this mass media as a weapon when it directed radio-based propaganda towards American troops by creating imaginary radio characters (Wakai 1995). Their anti-America propaganda continued for years together in the backdrop of atomic bombing on Hiroshima and Nagasaki. Even after 1950, the Radio did not lose its firm ground. Its waves were used by the nations against each other, particularly during conflict period (Wallace 2013). The outbreak of the Korean conflict, in June 1950, was to be the first major postwar test of countering the emerging threat of communism. The conflict started as a civil war between North Korea and Republic of South Korea.

During the Vietnam War in the 1960s and very early 1970s, radio propaganda was used against U.S. troops by the North Vietnamese. Trinh Thi Ngo, also known as "Hanoi Hannah", made three broadcasts-a-day directed towards American soldiers. She would list the newly killed or imprisoned Americans, try to convince American soldiers that the war was unjust and immoral, and in between it all, would play popular songs of the day. This kind of a broadcasting technique has also been used by other countries involved in conflicts against each other. By focusing on the medium of radio during World War II, Gred Horten has provided us with a window into an important change in radio broadcasting that has previously been ignored by historians. The depth of research, the book's contribution to our understanding of radio and the war makes his book, 'Radio Goes to War' an outstanding work. The wartime broadcasting provides an ominous example of difficult decisions to be made in the future. The alliance of big business, advertising, and wartime propaganda that Horten so convincingly illuminates takes on a heightened significance, especially as this relationship has tightened in the last several decades. This issue has also been raised by Michele Hilmes, a noted broadcaster and the author of "Radio Voices: American Broadcasting'. Horten's 'Radio Goes to War' is the first comprehensive and in-depth book at the role of domestic radio in the United States during the Second World War (Loviglio 2004). The book convincingly demonstrates that the radio broadcasting played a crucial role both in government propaganda and the counter propaganda and within the context of the broader cultural and political transformations of wartime America. Horten's absorbing narrative argues that no medium merged entertainment, propaganda and advertising more effectively than the medium of sound, i.e. radio (Loviglio 2004). As a result, America's wartime radio propaganda emphasised an increasingly corporate and privatised vision of America's future, with important repercussions for the war years and the postwar era.

\section{The German Radio Broadcasting}

During the world war, German stations broadcast not only war propaganda and entertainment for German forces dispersed through Europe and the Atlantic, but also provided air raid alerts. In Germany, before the Nazi assumption of power in 1933, radio in Germany was supervised by the Post Office. A listening fee of two Reich mark per receiver was paid most subsidies. Immediately following Hitler's assumption of power, Joseph Gobbels became head of 
the Ministry for Propaganda and Public Enlightenment. Non-Nazis were removed from broadcasting and editorial positions. Jews were fired from all positions. The Reichsrundfunk began to decline in popularity as the theme of Kampfzeit was continually played (Campbell 2019). Germany was easily served by a number of European medium wave stations, including the British Broadcasting Corporation (BBC) and domestic stations in France, Denmark, Sweden and Poland. It became illegal for Germans to listen to foreign broadcasts. However, foreign correspondents and key officials were exempt from this rule. The German Radio Station's shortwave broadcasting played an important part of fighting the cold war with Voice of America (VOA) and the BBC World Service augmented with Radio Free Europe (RFE) and Radio Liberty (RL) (Campbell 2019). Radio Moscow and others were broadcasting back, as well as jamming (transmitting to cause intentional interference) of the western voices was a common feature those days.

\section{USE OF RADIO DURING COLD WAR}

The Cold War was the period of ideological, economical confrontation and military competition between the USSR and the USA and their allies that had lasted from the middle of 1940s to the end 1980s. The official date of beginning of Cold War is considered as March 5, 1946 when Prime Minister of Great Britain, Winston Churchill had given his famous "The Sinews of Peace speech" in Westminster College, Fulton.. His phrase "Iron Curtain" became the basic of future ideological world division that had lied between Capitalist countries: the USA and its allies: Britain, Japan. France, West Germany and Canada; and Communist bloc: USSR, some countries of Eastern Europe, Cuba and China (Busch 2019).

The term 'Cold War' is well known since 1947, thanks to an American journalist, Walter Lippmann, who used this term to describe confrontation without "actual warfare" between USSR and USA, and their allies in his series of articles published in the New York Herald Tribune and also in the book "The Cold War, a Study in U.S. Foreign Policy". Owing to the absence of the real war between the USSR and the USA that was undesirable as it could have led to a nuclear war, this period was noted by numerous of proxy wars around the world like the Greek Civil War (1946-1949), Korean War (1950-1953), Vietnam War (1959-1975), Soviet-Afghan War (19781989) and wide scaled international ideological propaganda from both sides: USSR and USA (Boel 2019). The main method of transmission was radio because radio waves could easily reach many countries around the world. The radio had become cheaper and cheaper every year, and it was further very difficult to the ordinary citizen to identify the real location of a radio station. Soviet propaganda was characterised by features like glorifying of Soviet society, its workingclass and state military achievements and with the same breath describing Western countries as imperialistic and exploiting. To follow this line, the Soviet Union used Radio Moscow, Radio Peace and Progress, TASS and the Novosti Press Agency. Some enemy radio stations were also being frequently monitored by the Ideology Department (Boel 2019).

The USSR had several "international" radio stations that were actually located in the Soviet Republic and provided its point of view in the news. For example, The "National Voice of Iran" and "Radio Havana", which were functioning on the soil of the USSR, were provided a secret agenda of spreading the message of Communism in the region. On the other side as well, the main USA tool of international broadcasting and propaganda during cold war was radio because it was also considered the most accessible source of information by the Capitalist Bloc. America had made its best use to reach and attract international audience and promote capitalistic values. The United States had spent a lot of money on running of Voice of America (VOA). For instance, the budget of VOA in 1948 was equal to about $\$ 10,000,000$ (Craig 1988). 
During the Cold War, mass media was one of the main tools of international propaganda that equally were used by USSR and USA. The Soviet Union made it apparent after World War II that it intended to extend its reaches across all of Eastern Europe. The Soviets rapidly transformed from an American ally to a Communist enemy. In 1947, Voice of America once again expanded coverage to include a Russian language service. The U.S. government was optimistic that radio would be as successful penetrating the "Iron Curtain" as it had been in undermining German efforts in World War II (Craig 1988). By 1949, extreme fear of a communist infiltration was running rampant in the United States government. That year, Congress passed the Central Intelligence Agency Act. Aside from establishing the CIA, this Act also set forth plans for a new public diplomacy project -- a new radio service. An organisation called the National Committee for a Free Europe was designed to handle the concerns of Eastern European exiles. With secret funding from the CIA, this group created Radio Free Europe (RFE) in 1950. The station began broadcasting in July of that year from a transmitter in Germany (Kasprzak 2004). Three years later, Radio Liberty (originally named Radio Liberation from Bolshevism) was developed by a similar group of exiles. This service was put on air to target the Soviet Union. Also broadcasting from Germany, the Radio Liberty (RL) signal was jammed by Soviet leaders from day one. Jamming, as is described by the VOA, is a broadcasting noise, programming, or any other source of interference on the same frequency as a signal. During the Cold War, this technology was used by the Soviet government to prevent American radio signals from reaching out to its citizens. The United States has predominantly used radio in cold war era as a strategic tool to keep an eye on the happenings in those countries where it felt American command was not acceptable and to contain the spread of Communism. In achieving its designs, the US media portrayed USSR in different forms so as to generate anti-communist feelings worldwide. Over 30 years of radio wars passed before the United States government implemented another station (Kasprzak 2004). In 1985, the United States began to battle the closest communist threat -- Cuba and Fidel Castro. This Spanish-language service named "Radio Marti" continues to broadcast to the island nation from a radio tower transmitter in the Florida Keys (Craig 1988).

During the Cold War, Radio Free Europe and Radio Liberty broadcast uncensored news and commentary to people living in communist nations. As critical elements of the CIA's early covert activities against communist regimes in Eastern Europe, the Munich-based stations drew a large audience despite efforts to jam the broadcasts and ban citizens from listening to them. The history of the stations in the Cold War era reveals the perils their staff faced from the Soviet Union, Bulgaria, Romania and other Communist nations. It recounts in detail the murder of a writer Georgi Markov, the 1981 bombing of the stations by "Carlos the Jackal," infiltration by KGB agent Oleg Tumanov and other events (Kasprzak 2004). Appendices include security reports, letters between Carlos the Jackal and German terrorist Johannes Weinrich and other documents, many of which have never been published.

In a world where digital communication is king, where one can get the latest news on a mobile phone, it's easy to forget the fact that for many years the humble radio was the only method in which many people received information on world affairs. The assumption - which still rings true today - was that if one can control communication, one can control the population. This of course was no more true than in the Eastern Bloc during the Cold War as the statecontrolled media would broadcast only the information the state wanted people to see or hear, and more often than not this would be a straightforward propaganda exercise directed against the West. The United States National Security Council recognised this and decided that a response was required - albeit without official links to the U.S. government. The CIA was, therefore, tasked with generating this response. Richard Cumming's `Cold War Radio: The Dangerous History of American Broadcasting in Europe, 1950 - 1989' is the story of the radio-based facet of this response. For anyone with even the slightest interest in the machinery of the Cold War, it's safe 
to say that 'Cold War Radio"' deserves anybody's attention - Radio Free Europe and Radio Liberty played a pivotal psychological role during the Cold War (Critchlow 1999).

\section{RADIO AS A STRATEGIC TOOL IN POST COLD WAR ERA}

Even after the breaking of the Soviet Union and the so-called Communist Bloc, the mass media as a strategic tool is being put to use especially by the United States of America to date. This is being done to promote her interests, for which service of all types of media units, including Radio channels are being utilised worldwide. The United States has been promoting broadcasts to watch her interests in Iraq, Iran and Afghanistan where America and Americans have been facing the wrath of the terrorists or locals there. It continues to watch and comment on the developments of new countries after their disintegration from the USSR. The job has again been entrusted to Radio Free Europe and Radio Liberty, as it did in the pre- cold war era.

\section{Radio Free Europe/Radio Liberty (RFE/RL)}

This establishment, believed to have been working on the dictates of the CIA, has been one such media that kept the interests of the US intact by propagating the US line of action even during the times of Cold War. These Radio stations function under different names in different countries and claim they serve as a "surrogate" free press in 20 countries where the free flow of information was either banned by government authorities or not fully developed (Nohrstedt 2017). Presently headquartered in Prague, the RFE/RL broadcasts in 20 countries in 28 languages, including Iraq, Iran, Afghanistan and Russia. The Institution claims that it strengthens civil societies by projecting democratic values, combats ethnic and religious intolerance and promotes mutual understanding among people. Established at the beginning of the Cold War to transmit uncensored news and information to audiences behind the iron curtain, the RFE/RL has played a significant role in the collapse of communism and the rise of democracies in post-communist Europe. Many East European and Russian leaders, including Vaclav Havel and Boris Yeltsin, have testified to the importance of RFE and RL broadcasts in helping end the Cold War. Former Estonian President Lennart Meri nominated RFE/RL for the Nobel Peace Prize in 1991 (Nohrstedt 2017).

\section{Radio Azadi}

Presently, the RFE/RL is functioning in Afghanistan under the name and style of Radio Free Afghanistan (known locally as "Radio Azadi") (Wang 2018). It was first aired across the country from 1985-93, following the Soviet invasion of Afghanistan. The current incarnation of Radio Azadi went on the air in January 2002 following the ouster of the Taliban by U.S-led forces. Radio Azadi claims to have become the most popular radio station in the country and produces a variety of programmes -- from special media capsules for youth and women to political satires and music and literary programmes. Radio Azadi is noted for its numerous programmes on women's rights and on the establishment and function of democratic institutions. In May 2002, U.S. First Lady Laura Bush addressed the people of Afghanistan in a speech delivered from the Prague headquarters of RFE/RL. In particular, she noted improvements in the lives of the country's women and children. "I'm confident Afghanistan can build a future of peace and freedom, and America will be your friend and partner in achieving it," she made a strategic comment through the medium of Radio. On humanitarian front, the Radio Azadi claims it has reunited many family members separated during Afghanistan's decades of war (Wang 2018). It plays the programmes like interviews with suicide bombers who impress upon others in their local languages and dialects to stop these acts of evil. The Radio Station also provides a cultural relief 
to the war-ravaged of Afghanistan by playing their folk tunes. Radio Azadi also covered all aspects of the historic Peace Jirga (grand meeting) in 2007 between tribal leaders on both sides of the Afghan-Pakistani border aimed at halting cross-border terrorist activities.

\section{The Radio Free Iraq}

In Iraq, the RFE/RL functions under the name and style as Radio Free Iraq by airing programmes in Arabic language. It has set-up transmitters at places located near Baghdad, Irbil, Al-Basrah, Kirkuk, Mosul, Al-Nasiriyah, Samawah, Al-Sulaymaniyah, Al-Najaf, and Al-Hillah, Tikrit (Boler 2006). Strategic broadcasting was established by the U.S. Congress in 1998 and began relaying programmes in October that year. On several notable occasions, Radio Free Iraq (RFI) was ahead of local media in reporting events of mass interest whileas the local media had been avoiding touching subjects like human rights violation, violence, corruption, etc. For its bold approach and content, the RFI had to pay the price as well (Boler 2006). In 2007, two of its correspondents - Khamail Muhsin Khalaf and Nazar Abdulwahid alRadhi were killed while carrying out their journalistic assignments in Iraq. A third, Jumana al-Obaidi, was kidnapped in Baghdad and held for two weeks before being released. RFI claims it has a unique format with a lot of serious content, compared to the entertainment offering of its competitors. Its audience has indicated that this is a strong, positive feature of the radio. Listeners appreciate RFI's distinctive musical format, which emphasizes classical Iraqi music and songs. The Radio Free Europe/Radio Liberty is funded by the U.S. Congress through the Broadcasting Board of Governors (BBG). The BBG is a bipartisan federal agency overseeing all U.S international broadcasting services. In addition to RFE/RL, this includes Voice of America, Alhurra Radi Sawa and Radio Marti. RFE/RL also maintains a corporate office in Washington, D.C. Although there is an apprehension that the U.S. government is directly involved in RFE/RL's operational or editorial decisions, the management of the radio station, however, maintains that its governing board, the BBG, serves by law as a firewall to protect editorial independence. It claims that in Afghanistan, over 50 percent of the adult population listens to its programmes, where it broadcasts mainly in the Pushtoo language. The radio station broadcasts over 1,000 hours of radio programming every week, and listeners can tune in on shortwave frequencies across the entire broadcast region.

Even after the end of Cold War era, the US Congress funded Radio Station continues to project the US policy matters through its radio programmes in countries like Iraq and Afghanistan, which are in the neighbourhood of Nigeria and where US interests are at stake. The radio station claims its mission is more relevant in the present times as many countries in the former Soviet sphere have recently seen a dramatic reversal of democratic progress. Journalists, there are increasingly under threat of extremists as RFE/RL remains a crucial source of accurate information beyond the reach of autocratic governments.

\section{CONCLUSION}

Various nations across the globe have always used media as a tool to safeguard their strategic interests by promoting their ideologies, cultural or democratic values; policies and priorities, political ambitions and at the same time used media in propaganda and counterpropaganda operations both in times of peace and war. Such an exercise has mostly been accomplished through official media under the control of the Governments or funded by parties or regimes in power. Whether in democratic, communist or theocratic nations or in countries ruled by Army or dictators, the official media has mostly been used to safeguard the strategic interests and security concerns of the establishment. The government-controlled media while carrying forward three basic principles of educating, entertaining and informing the audience, has also been extensively used as a psychological warfare and a propaganda tool in combating insurgency 
and conflict situations. The medium has proved as a strong tool while fighting the war of words and boosting the morale of the security forces across the nations. The highest importance of Radio as a national medium for every country, including America, Germany, Japan, and Britain was reinforced during World War II. Since there was no other well organised medium of mass communication, Radio was the only tool to have a liaison with the armed forces and public and at the same time used as a strong effective and strategic weapon to fight the wars.

\section{REFERENCES}

Boel, B. (2019). Western journalism in the Soviet bloc during the Cold War: themes, approaches, theses. Cold War History, 19(4), 593-614. https://doi.org/10.1080/14682745.2019.1670421

Boler, M. (2006). The Transmission of Political Critique after 9/11: "A New Form of Desperation"? M/C Journal, 9(1). https://doi.org/10.5204/mcj.2595

Busch, P. (2019). Comrades at War: Soviet Radio Broadcasting during the 1979 Sino-Vietnamese War. Media History, 25(4), 479-492. https://doi.org/10.1080/13688804.2019.1652580

Campbell, B. B. (2019). German Radio Before Broadcasting: Scientists, War, and Imperialism. In The Radio Hobby, Private Associations, and the Challenge of Modernity in Germany (pp. 77-89). https://doi.org/10.1007/978-3-030-26534-2 3

Chatterjee, R. K. (1973). Mass communication. New Delhi: National Book Trust, India;[sole distributors: Thomson Press (India).

Chatterjee, R. K. (1973). Mass communication. New Delhi: National Book Trust.

Craig, R. S. (1988). American Forces Network in the Cold War: Military Broadcasting in Postwar Germany. Journal of Broadcasting \& Electronic Media, 32(3), 307-321. https://doi.org/10.1080/08838158809386704

Critchlow, J. (1999). Western Cold War Broadcasting. Journal of Cold War Studies, 1(3), 168175. https://doi.org/10.1162/152039799316976841

DeFleur, M. L., \& Ball-Rokeach, S. (1988). Theories of Mass Communication. New York: Longman.

EDET, F. F. (2015). BOKO HARAM: A LEGAL AND BIBLICAL PERSPECTIVE. JOURNAL OF INTEGRATIVE HUMANISM GHANA, 94.

Edet, F. F. (2019). Dress code for women in Islam: a sociological investigation. Lwati: A Journal of Contemporary Research, 16(3), 182-188.

Edet, F. F. (2019). The concept of worship in Islam. Lwati: A Journal of Contemporary Research, 16(4), 125-130.

Edgley, A. (2002). The social and political thought of Noam Chomsky (Vol. 24). Psychology Press.

Essien, E. (2003). The Performing Artist and Marketing Problems in Nigeria. Theatre Studies Review, 3(1), 44-55.

Essien, E. (2005). The Theatre Administrator and Conflict Resolution in the Theatre. Nduñode, 6(2).

Essien, E. (2005). Tourism and Nigerian Traditional Festivals. The Parnassus, 2(5).

Essien, E. (2015). Exploring Theatre For Development (Tfl) Praxis In An. Journal of Integrative Humanism Vol. 5 No. 1, 41.

Essien, E. (2017). Video Film Piracy in Nigeria: Interfacing to Integrate the Pirate. Lwati: A Journal of Contemporary Research, 14(1), 157-166.

Essien, E. (2020). Theater for development in contemporary Nigeria: problems and prospects. International Journal of Humanities and Innovation (IJHI), 3(1), 17-21.

Hilmes, M. (1997). Radio voices: American broadcasting, 1922-1952. U of Minnesota Press. 
106 Predestinasi

Volume 14, No. 1, Juni 2020 Hal. 93- 106

Iosifidis, P., \& Wheeler, M. (2018). Modern Political Communication and Web 2.0 in Representative Democracies. Javnost, $\quad$ 25(1-2), 110-118. https://doi.org/10.1080/13183222.2018.1418962

Kasprzak, M. (2004). Radio free europe and the Catholic Church in Poland during the 1950s and 1960s. Canadian Slavonic Papers, 46(3-4), 315-341. https://doi.org/10.1080/00085006.2004.11092362

Lasswell, H. (1927). Propaganda technique in the world war/Harold D. Lasswell. London: Kegan Paul, Trench, Trubner \& Co.

Lee, A. M., \& Lee, E. B. (2001). Propaganda Analysis. [Online: web] Accessed; URL:http://carmen.artsci.washington.edu/

Loviglio, J. (2004). Radio in Wartime: The Politics of Propaganda, Race, and the American Way in the Second World War. American Quarterly, 56(4), 1079-1087. https://doi.org/10.1353/aq.2004.0061

Nohrstedt, S. A. (2017). New War Journalism. Nordicom Review, 30(1), 95-112. https://doi.org/10.1515/nor-2017-0141

Oetzel, J. G., \& Ting-Toomey, S. (2006). The Sage handbook of conflict communication: Integrating theory, research, and practice. Sage Publications.

Paletz, D. L., \& Schmid, A. P. (Eds.). (1992). Terrorism and the Media. SAGE Publications

Pavarala, V., \& Malik, K. K. (2007). Other voices: The struggle for community radio in India. SAGE Publications India.

Snowden, C., \& Green, K. (2007). Media Reporting, Mobility and Trauma. M/C Journal, 10(1). https://doi.org/10.5204/mcj.2597

Wakai, N. (1995). Dawn in radio technology in Japan. IEE Conference Publication, 411, 51-56. https://doi.org/10.1049/cp:19950789

Wallace, C. J. (2013). Japan's strategic pivot south: Diversifying the dual hedge. International Relations of the Asia-Pacific, 13(3), 479-517. https://doi.org/10.1093/irap/lct011

Wang, X. (2018). Radio Culture in Cold War Hong Kong. Interventions, 20(8), 1153-1170. https://doi.org/10.1080/1369801X.2018.1460218 